\title{
Benthic Foraminiferal and Calcareous Algae Assemblages in the Tirgan Formation (Urgonien Facies Type) in South Flank of Ghorogh Syncline (North of Chenaran), NE Iran
}

\author{
Hoda Yavarmanesh ${ }^{*}$, Seyed Hamid Vaziri ${ }^{1}$, Ali Asghar Aryaei ${ }^{2}$, Davood Jahani ${ }^{1}$, \\ Mohsen Pourkermani' ${ }^{1}$, Ebrahim Khademi Bouriabadi ${ }^{3}$ \\ ${ }^{1}$ Department of Geology, North Tehran Branch, Islamic Azad University, Tehran, Iran \\ ${ }^{2}$ Department of Geology, Mashhad Branch, Islamic Azad University, Mashhad, Iran \\ ${ }^{3}$ Department of Geology, University of Tehran, Tehran, Iran \\ Email: ${ }^{\star}$ yavarmanesh@yahoo.com
}

How to cite this paper: Yavarmanesh, H., Vaziri, S.H., Aryaei, A.A., Jahani, D., Pourkermani, M. and Bouriabadi, E.K. (2017) Benthic Foraminiferal and Calcareous Algae Assemblages in the Tirgan Formation (Urgonien Facies Type) in South Flank of Ghorogh Syncline (North of Chenaran), NE Iran. Open Journal of Geology, 7, 796-805. https://doi.org/10.4236/ojg.2017.76054

Received: May 1, 2017

Accepted: June 5, 2017

Published: June 8, 2017

Copyright $\odot 2017$ by authors and Scientific Research Publishing Inc. This work is licensed under the Creative Commons Attribution International License (CC BY 4.0).

http://creativecommons.org/licenses/by/4.0/

\begin{abstract}
In this research, the Tirgan Formation in the south flank of Ghorogh Syncline (north of Chenaran), northeastern Iran with the thickness of 251 was studied. This section consists of limestone, marly limestone and shale with impressions of echinoderms toxasteridae family, many of foraminifera from orbitolinidae family and also lots of calcareous algae that create facies variation along with other non-skeletal allochems. Micropaleontological investigation has been carried out on 90 thin-sections. These criteria reveal that an equivalent of the Urgonian facies type (in France-Swiss area) and open marine, low depth sedimentary basin are extended in the Kopet-Dagh basin. In this article, we tried to introduce some of the important foraminiferal and calcareous algal assemblages of this area.
\end{abstract}

\section{Keywords}

Tirgan Formation, Ghorogh Syncline, Foraminifera, Calcareous Algae

\section{Introduction}

The Tirgan Formation is a Lower Cretaceous succession in the Kopet Dagh basin in northeast of Iran which mainly consists of micritic limestones, thick-bedded bio-micritic limestones, shaly limestones, marly limestones and bio-sparite limestones [1]. The study area is located in south flank of Ghorogh Syncline (north of Chenaran) in the Kopet-Dagh basin with coordinates: $36^{\circ} 50^{\prime} 38^{\prime \prime} \mathrm{N}$ and $59^{\circ} 02^{\prime} 38^{\prime \prime} \mathrm{E}$ (Figure 1). The Tirgan Formation in study area with a thickness of $251 \mathrm{~m}$, consists 


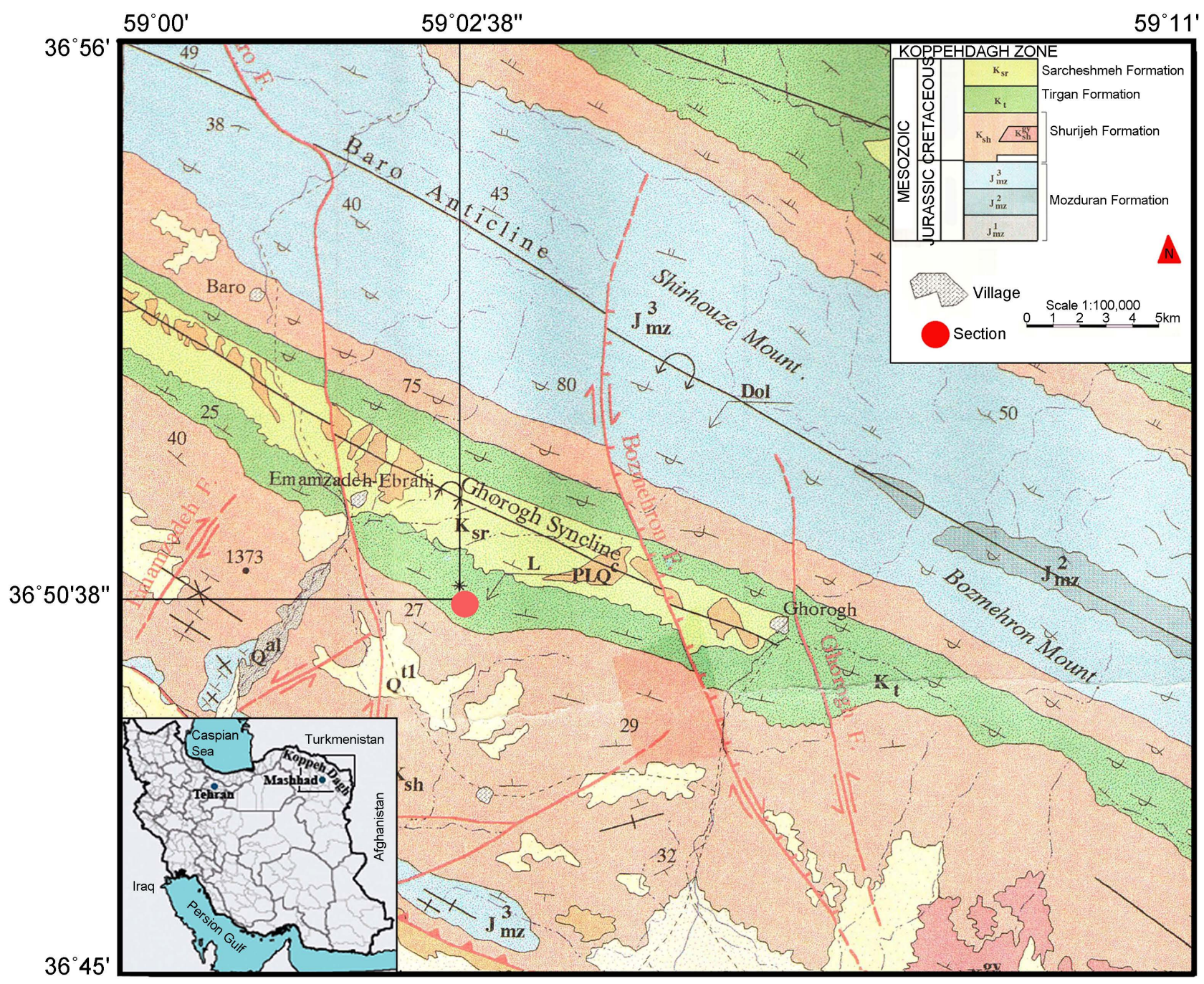

Figure 1. Location map of the Tirgan Formation in south flank of Ghorogh Syncline (Kopet Dagh basin), NE Iran.

of limestone, marly limestone and shale (Figure 2). Detailed micropaleontological investigations have been carried out on one section of the Tirgan Formation supported by the analysis of 90 thin-sections. In this section, the benthic foraminiferal assemblages constitute the largest proportion of the total microfaunal content in terms of abundance.

\section{Geological Setting}

The Kopet Dagh mountain range represents a NE-trending about $650 \mathrm{~km}$ long and about $200 \mathrm{~km}$ wide active fold belt at the frontier between Turkmenistan and Iran, east of the Caspian Sea. It was formed on Hercynian metamorphosed basement at the SW margin of the Turan Platform and is composed of about 10 $\mathrm{km}$ of Mesozoic and Tertiary sediments (mostly carbonates). Like to the Zagros Mountains, the Kopet Dagh was folded in to long linear NW-SE trending folds during the last phase of the Alpine orogeny in Plio-Pleistocene times. No magmatic rocks are exposed in Kopet Dagh except those at the basement occurring in the Aghdar band tectonic window and some Triassic basic dikes. The studied 


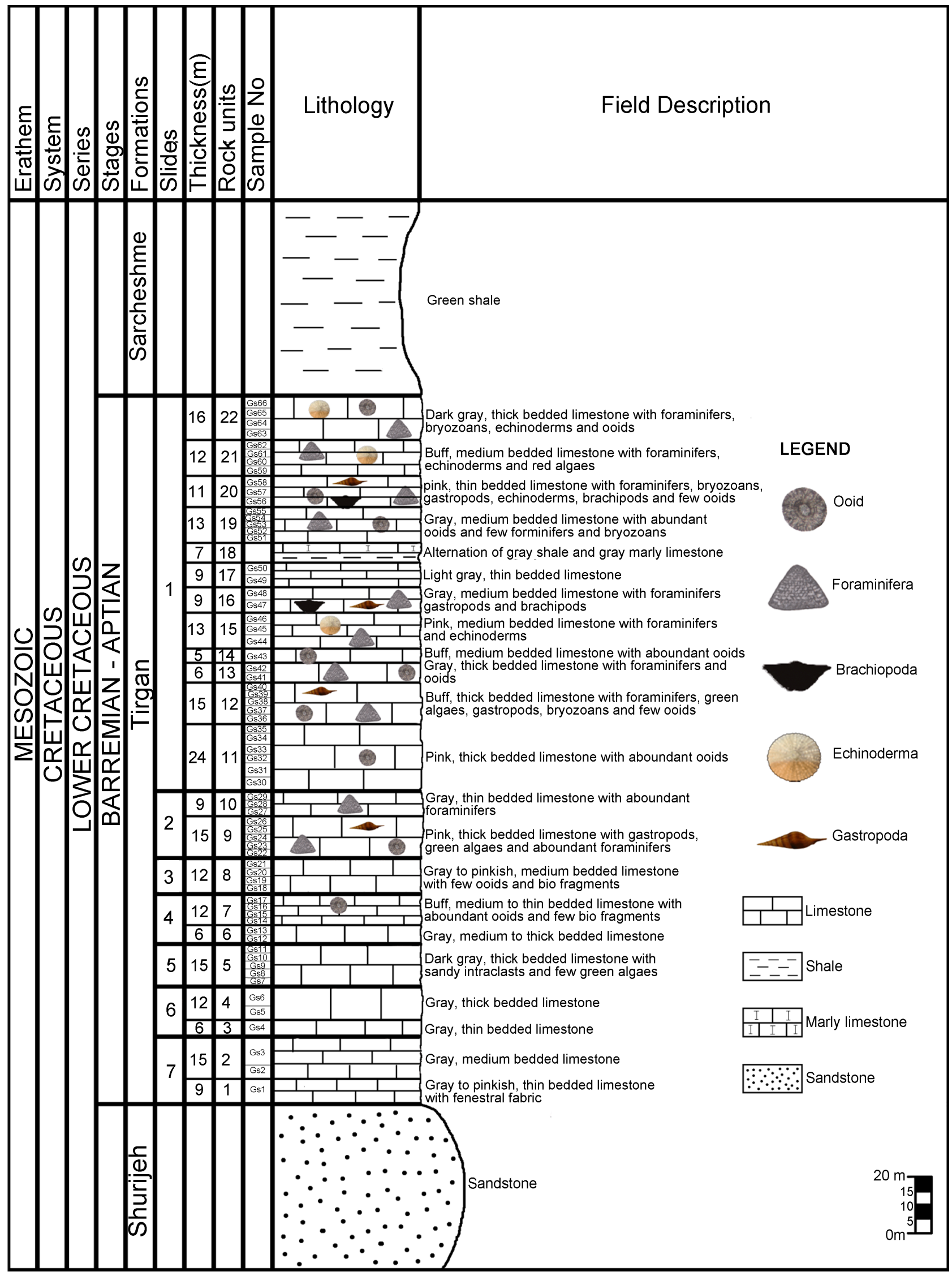

Figure 2. Stratigraphic section of the Tirgan Formation in south flank of Ghorogh Syncline. 
samples are from the Barremian-Aptian Tirgan Formation referring to the Tirgan Valley in the eastern central Kopet Dagh sedimentary basin in the northeast of Iran. The name, introduced by geologists of the National Iranian oil company [2] [3], applies to a feature-forming unit of massively bedded, oolitic and organo-detrital limestones occurring throughout the Kopet Dagh mountain range. For the eastern part of Kopet Dagh, thickness of $50 \mathrm{~m}$ or less is indicated but in the type area of the Tirgan Valley the thickness is about $700 \mathrm{~m}$ [3]. The Tirgan Formation overlies the Shurijeh Formation and underlies by the Sarcheshmeh Formation; the contacts with both are conformable and a transitional inter-fingering between the Tirgan and Shurijeh formations have been observed in the southeastern Kopet Dagh. The lithology of the Tirgan Formation includes oolithic, partly fossiliferous (e.g. orbitolinid limestones), partly marly limestones, and marls allowing further differentiation of the formation. The age of Tirgan Formation was essentially Neocomian, inplaces extending as high as Aptian. Barremian deposits of the Tirgan Formation may reach up to $300 \mathrm{~m}$ thickness and consist of alternating calcareous sand and oolitic sandy limestone containing bryozoans, calcareous algae and both benthonic and planktonic foraminifera [4]. The Aptian part of the Tirgan Formation may reach up to $1100 \mathrm{~m}$ in thickness and is mainly represented by massive limestones; its foraminiferal fauna includes beside others orbitolinids such as Palorbitolina lenticularis.

\section{Discussion}

Chenaran area is a part of Kopet Dagh sedimentary basin located in the Khorasan Razavi. In this area, some outcrops of the Mozdooran, Shurijeh, Tirgan and Sarcheshmeh formations are present with the Jurassic and Cretaceous age. This area is located about $25 \mathrm{~km}$ north of Chenaran. In this section, the thickness of the Tirgan Formation is $251 \mathrm{~m}$ in south flank of Ghorogh Syncline. For micropaleontological studies, 66 samples were taken and 90 thin-sections were prepared. Several references such as [5]-[11] used to identify benthic foraminifera and calcareous algae.

The following benthic foraminifera have been identified (Figure 3 and Figure 4): Palorbitolina lenticularis, Orbitolina sp., O. conoidea, O. discoidea, O. kurdica, Simplorbitolina manasi, Dictyoconus sp., D. arabicus, D. cuvillieri, D. pachymarginalis, Vercorsella sp., V. arenata, Cuneolina sp., C. sliteri, Nautiloculina bronimanni, Nezzazata isabellae, Bolivinopsis rhopaloides, Praechrysalidina sp., P. infracretacea, $P$. cf. infracretacea, Comaliama sp., Trocholina sp., T. odukpaniensis, T. cf. alpina, Novalesia sp., Debariana hahounerensis, Istriloculina eliptica, Triloculina sp., Rumanoloculina sp., $R$. pseudominima, $R$. ponticuli, $R$. robusta, Charentia cuvillieri, Debariana sp., Paleodictyoconus glanensis, Istriloculina sp.

Also, the following calcareous algae (mainly dasycladales) have been identified (Figure 5): Salpingoporella sp., S. muehlbergii, S. dinarica, Boueina sp., B. pygmaea, B. hochstetteri, Arabicodium sp., A. orientalis, Cylindroporella sp., C. sugdeni, Halimeda sp., Carpathoporella fontis, Triploporella marsicana, Kopetdagaria sphaerica, Permocalculus sp. 

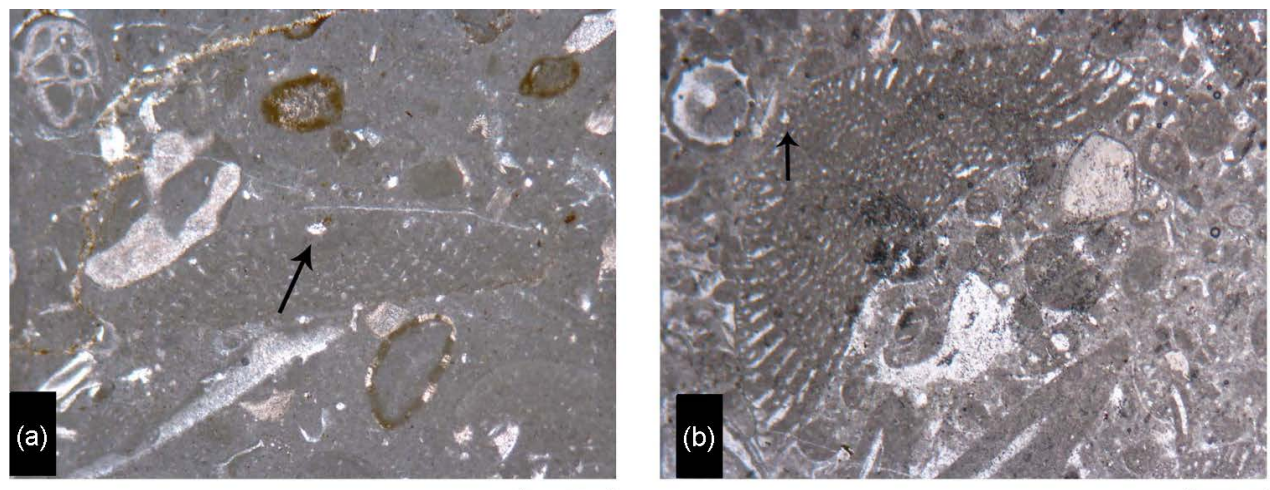

$0.07 \mathrm{~mm}$
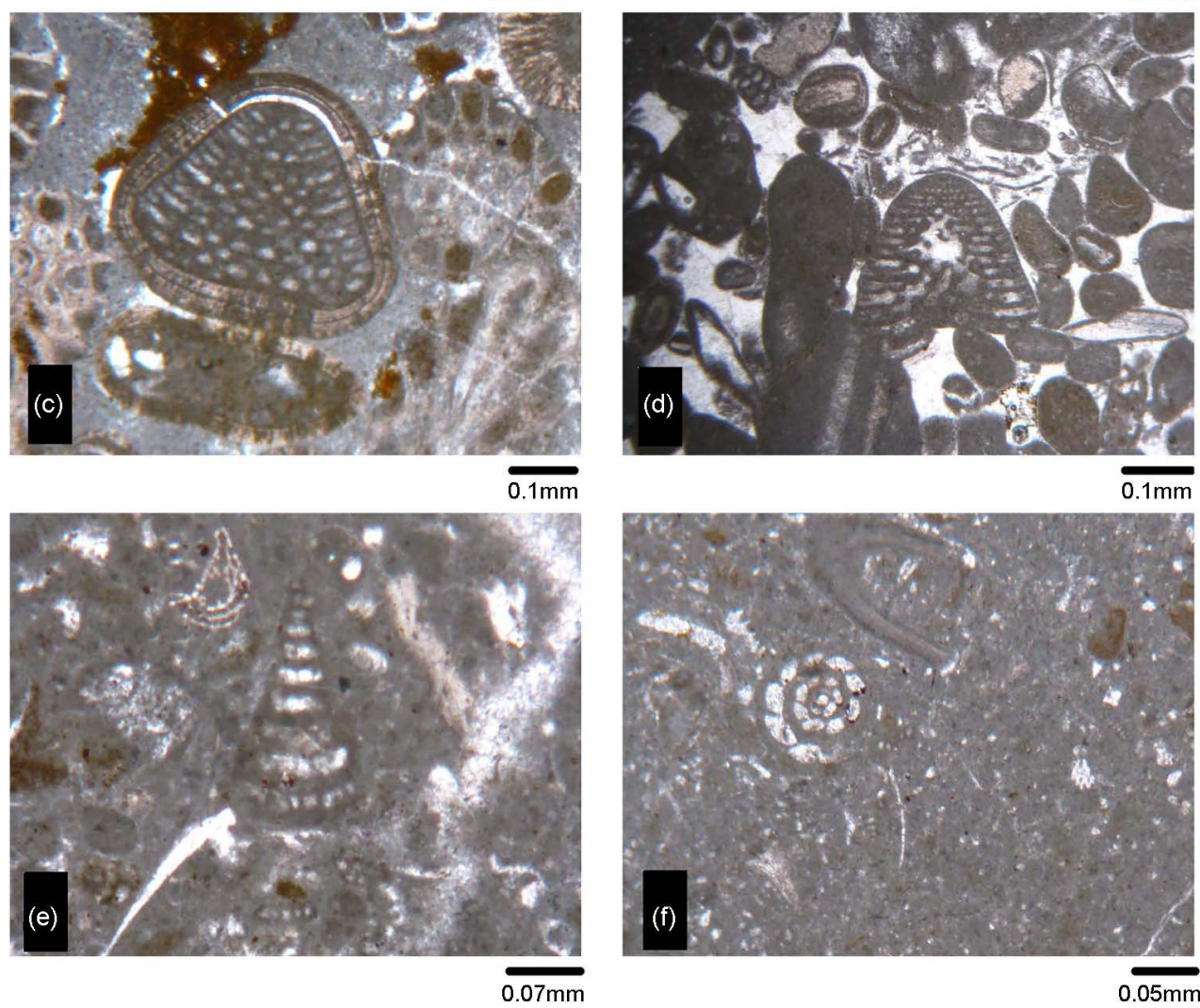

Figure 3. Benthic foraminifera: (a) Palorbitolina lenticularis, (b) Palorbitolina lenticularis, (c) Simplorbitolina manasi, (d) Dictyoconus pachymarginalis, (e)Cuneolina sliteri, (f) Charentia cuvillieri.

Based on the above-mentioned microfauna four biozones have been recognized as follow:

\section{Benthic Foraminifera Biozones:}

1) Trocholina odukpaniensis Range Zone: This biozone is associated with the following foraminifers: Trocholina odukpaniensis, Cuneolina sliteri, Novalesia sp., Praechrysalidina infracretacea, Praechrysalidina cf. infracretacea, Bolivinopsis rhopaloides, Comaliama sp., Nezzazata isabellae, Nautiloculina bronimanni, Vercorsella arenata, Cuneolina sp., Trocholina sp., Vercorsella sp. (Figure 6). Trocholina odukpaniensis Range Zone is specified with appearance and extinction of Trocholina odukpaniensis with a thickness of $7 \mathrm{~m}$ (Gs 25, Gs 26) and the age of this biozone is Late Barremian. 

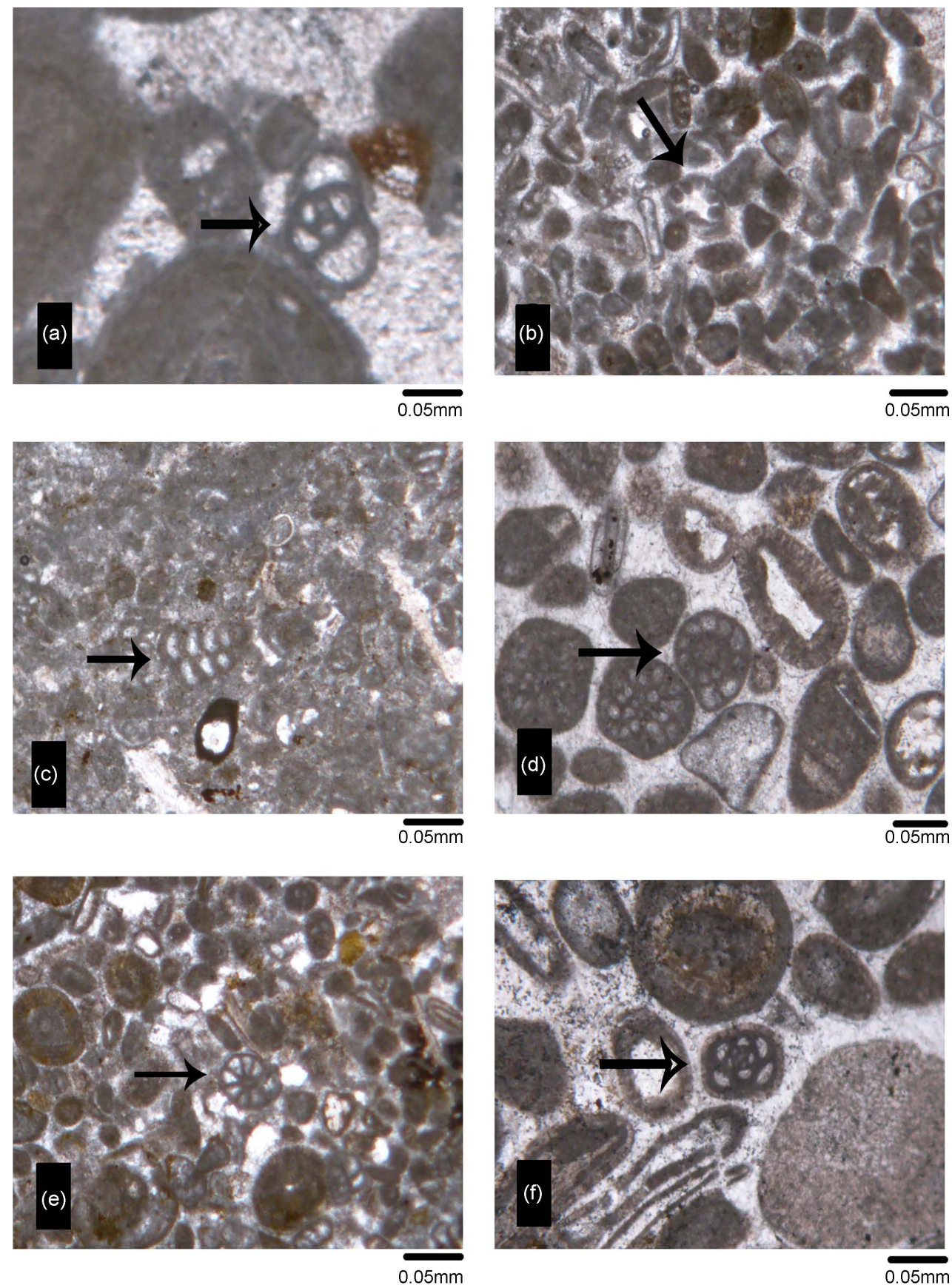

Figure 4. Benthic foraminifera: (a) Istriloculina eliptica, (b) Trocholina odukpaniensis, (c) Vercorsella arenata, (d) Debariana hahounerensis, (e) Nezzazata isabellae, (f) Rumanoloculina robusta.

2) Charentia cuvillieri-Debariana hahounerensis Assemblage Zone: This biozone is associated with the following foraminifers: Charentia cuvillieri, Debariana hahounerensis, Istriloculina eliptica, Praechrysalidina sp., Triloculina sp., Rumanoloculina pseudominima, Orbitolina sp. (Figure 6). Charentia cuvillieri-Debariana hahounerensis Assemblage Zone is specified with appearance of Charentia cuvillieri and extinction of Debariana hahounerensis with a thickness of $28 \mathrm{~m}$ (Gs 34 to Gs 41) and the age of this biozone is Early Aptian.

3) Dictyoconus pachymarginalis Range Zone: This biozone is associated 

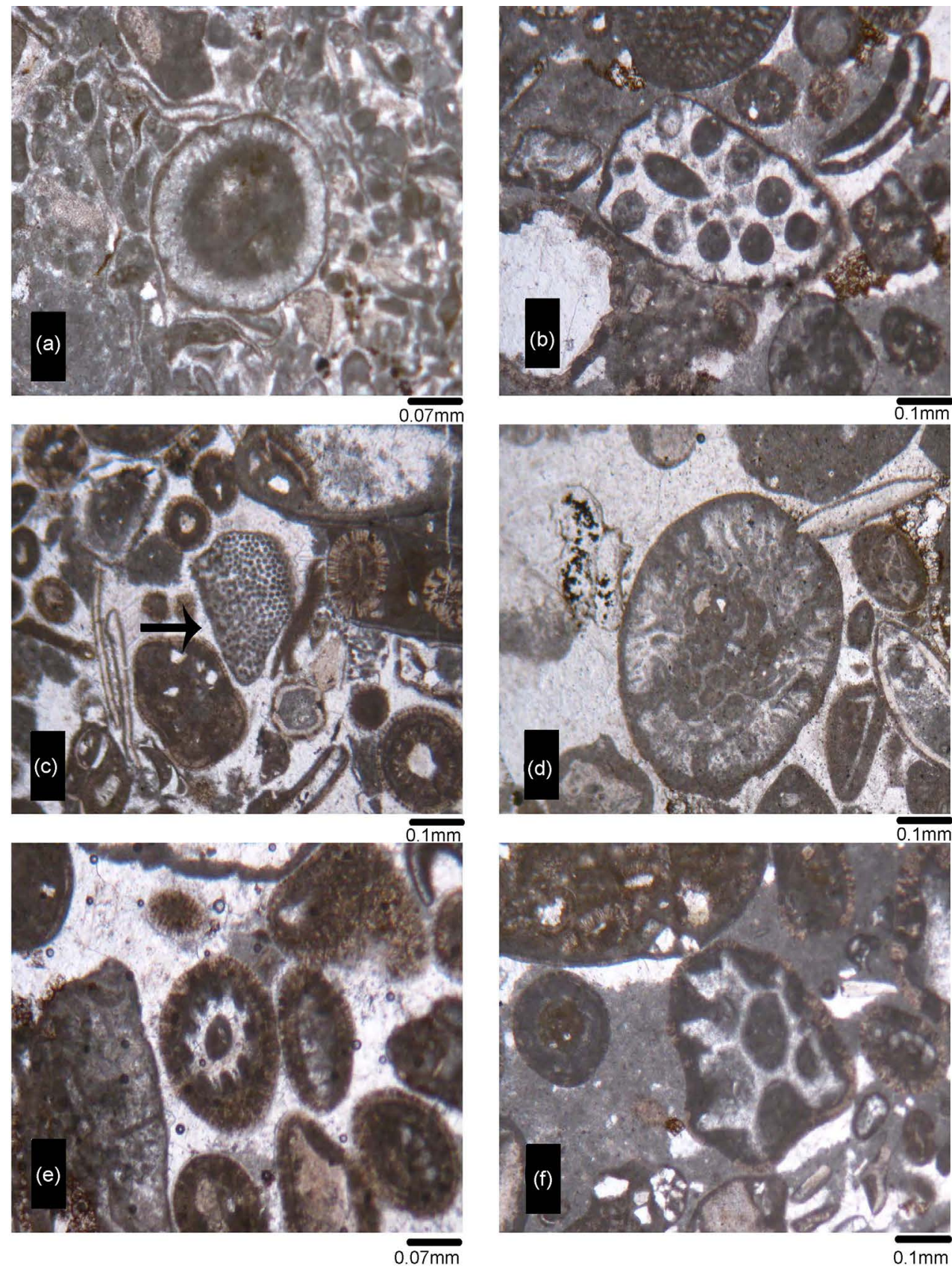

Figure 5. Calcareous algae: (a) Arabicodium orientalis, (b) Cylindroporella sp., (c) Permocalculus sp., (d) Boueina hochstetteri, (e) Carpathoporella fontis, (f) Kopetdagaria sphaerica.

with the following foraminifers: Dictyoconus pachymarginalis, Palorbitolina lenticularis, Orbitolina conoidea, Orbitolina discoidea, Rumanoloculina sp., Rumanoloculina robusta (Figure 6). Dictyoconus pachymarginalis Range Zone is specified with appearance and extinction of Dictyoconus pachymarginalis with a thickness of 39 m (Gs 35 to Gs 45) and the age of this biozone is Early Aptian.

Calcareous Algae Biozone:

4) Boueina hochstetteri-Cylindroporella Assemblage Zone: This biozone is associated with the following calcareous algae: Boueina hochstetteri, Cylindroporella sp., Boueina pygmaea, Arabicodium orientalis, Boueina sp., Cylindropo- 


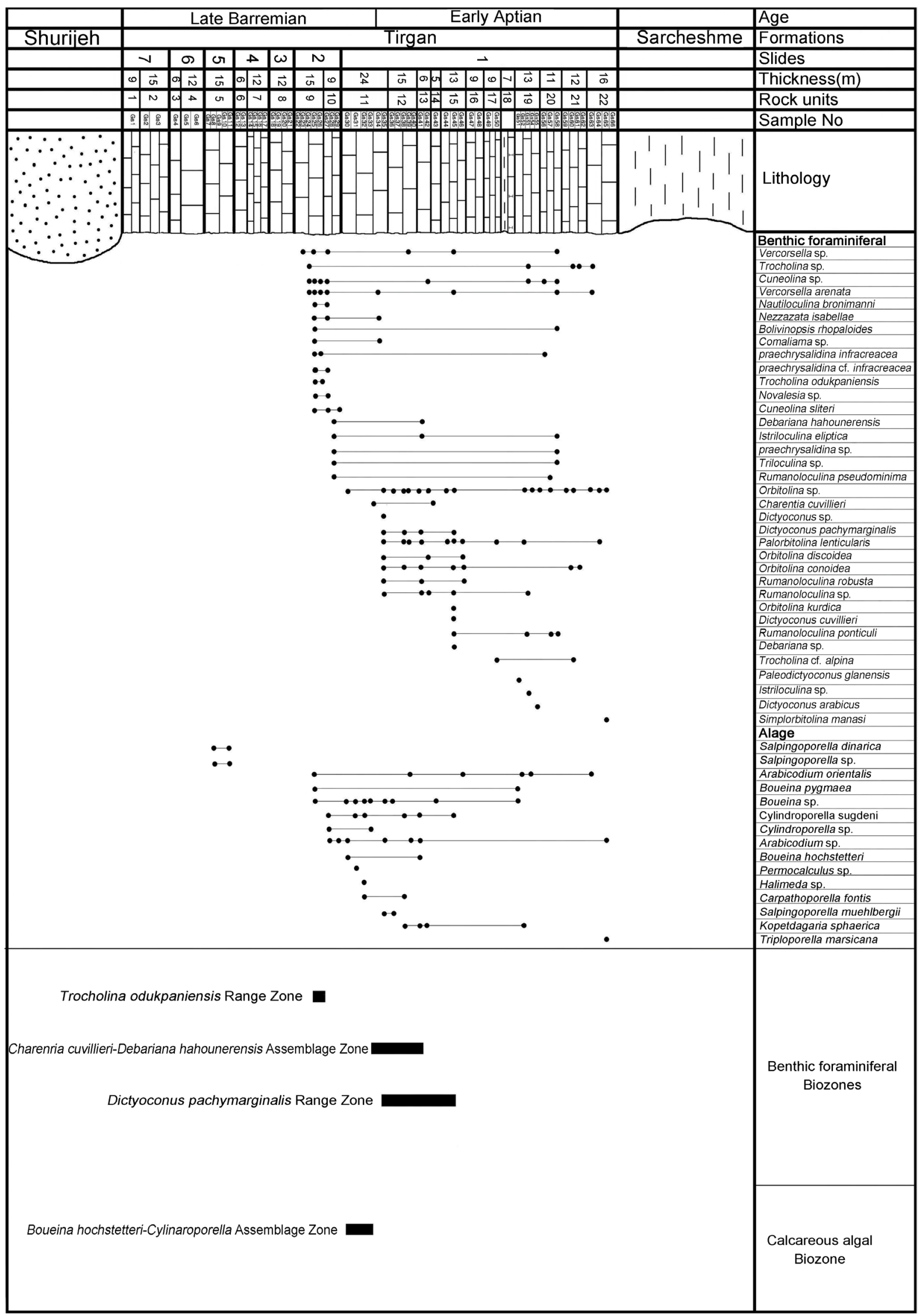

Figure 6. Main foraminiferal and calcareous algae range chart. 
rella sugdeni, Arabicodium sp. (Figure 6). Boueina hochstetteri-Cylindroporella Assemblage Zone is specified with appearance of Boueina hochstetteri and extinction of Cylindroporella sp. with a thickness of $16 \mathrm{~m}$ (Gs 30 to Gs 33) and the age of this biozone is Late Barremian.

According to the mentioned biozones, the Late Barremian-Early Aptian age is suggested for the formation.

Overall, the importance of this research is that it will lead to determine the age of the Tirgan Formation more precisely and also it conveniently enables us to compare this formation with other sections of the basin on the future studies.

\section{Conclusions}

The main results of the present research as follow:

1) Tirgan Formation in the study area consists mainly of medium- to thickbedded biogenic oolithical limestones with intercalations of shales.

2) 19 genera and 21 species of foraminifera and 9 genera and 9 species of calcareous algae have been determined. 2 Range Zone and 1 Assemblage Zone of benthic foraminifera (Trocholina odukpaniensis Range Zone, Charentia cuvillieri-Debariana hahounerensis Assemblage Zone, Dictyoconus pachymarginalis Range Zone) and 1 Assemblage Zone of calcareous algae (Boueina hochstetteri-Cylindroporella Assemblage Zone) have been identified.

3) The existence of Urgonian facies in the NE Iran is accurately certified according to the micro-and macrofauna in the studied area.

4) Based on the identified benthic foraminifera as well as dasycladalean algae, the Late Barremian-Early Aptian age can be ascribed for the Tirgan Formation in the studied area.

\section{References}

[1] Afshar-Harb, A. (1994) Geology of Kopet-Dagh. Geol Survey Iran publ, Vol., 109-124.

[2] Afshar-Harb, A. (1970) Geology of Sarakhs Area and Khangiran Gas Field. Nat. Iran. Oil Co. Paper Presented at 8 th Session of ECAFE Working Party of Senior Geologists, Bandung.

[3] Afshar-Harb, A. (1969) A Brief History of Geological Exploration and Geology of the Sarakhs Area and the Khangiran Gas Field. The Bulletin of the Iranian Petroleum Institute, 37, 43-262.

[4] Kalantari, A. (1969) Foraminifera from the Middle Jurassic-Cretaceous Successions of Koppet Dagh Region (NE, Iran). Teheran National Iranian Oil Company, Geol. Labor., Publ, 3, 1-298.

[5] Arnaud Vanneau, A. and Sliter, W. (1995) Early Cretaceous Shallow-Water Benthic Foraminifers and Fecal Pellets from Leg 143 Compared with Coeval Faunas from the Pacific Basin, Centeral America, and the Tethys. Proceedings of the Ocean Drilling Program, Scientific Results, 143, 537-564.

https://doi.org/10.2973/odp.proc.sr.143.252.1995

[6] Arnaud Vanneau, A., Conard, M., Deloffre, R., et al. (1991) Distribution of Lower Cretaseous Foraminifera and Dasy-cladal Algae of the Adriatic Plate. In: Vlahović, I. and Velić, I., Eds., Some Aspects of the Shallow Water Sedimentation on the 
Adriatic Carbonate Platform (Permian to Eocene), Inst. of Geology Zagreb, 22-26.

[7] Husines, A. and Sokac, B. (2006) Early Cerataceus Benthic Associaitions (Foraminifera and Calcareous Algae) of a Shallow Tropical-Water Platform Environment (Mijet Island, Southern Croatia). Cretaceous Research, 27, 418-441.

[8] Kuss, J. and Conrad, M. (1991) Calcareous Algae from Cretaceous Carbonates of Egypt, Sinai, and Southern Jordan. Journal of Paleontology, 65, 869-882. https://doi.org/10.1017/S0022336000037847

[9] Schlagintweit, F. and Dragastan, O. (2004) Pinnatiporidium Untersbergensis N. SP; a New Siphonous Green Alga of the Family Protohalimedaceae Dragastan, Littler \& Littler 2002 from the Upper Jurassic of the Northern Calcareous Alps (Austria). Acta palaeontologica Romaniae, 4, 455-462.

[10] Schroeder, R., Schenk, K., Cherchi, A. and Schwizer, B. (2007) A Sur la Presence de Grands Foraminifers age Aptien Superieur Dans 1 Urgonien de la Napped u Wildhorn (Suisse Centrale). Note Preliminaire. Revue de paleobiologie, Geneve, 26, 665669.

[11] Taherpour Khalil Abad, M., Aryaei, A., Ashouri, A. and Hosseini, S. (2010) Benthic foraminiferal Assemblages in Tirgan Formation (Urgonien Facies Type), West of Kopet-Dagh Sedimentary Basin, NE of Iran. 1st Int. Applied Geol Congr Dept of Geol, Islamic Azad Univ Mashad Branch, Iran, 26-28 April 2010, 1027-1031.

\section{Submit or recommend next manuscript to SCIRP and we will provide best service for you:}

Accepting pre-submission inquiries through Email, Facebook, LinkedIn, Twitter, etc. A wide selection of journals (inclusive of 9 subjects, more than 200 journals) Providing 24-hour high-quality service

User-friendly online submission system

Fair and swift peer-review system

Efficient typesetting and proofreading procedure

Display of the result of downloads and visits, as well as the number of cited articles Maximum dissemination of your research work

Submit your manuscript at: http://papersubmission.scirp.org/

Or contact ojg@scirp.org 